\title{
PENGEMBANGAN WEBSITE UNIT PENELITIAN DAN PENGABDIAN KEPADA MASYARAKAT DAN PENERAPAN JURNAL ELEKTRONIK BERBASIS OPEN SOURCE DI POLITEKNIK NEGERI KUPANG
}

\author{
Imanuel Christian Mauko ${ }^{1}$, Nicodemus Mardanus Setiohardjo², \\ Fredrik Paulus Noach ${ }^{3}$
}

\begin{abstract}
Abstrak :
Salah satu kegiatan UP2M PNK sebagai pengelola kegiatan penelitian dan pengabdian kepada masyarakat di Politeknik Negeri Kupang adalah menyampaikan informasi terkait pelaksanaan kegiatan penelitian dan pengabdian masyarakat kepada civitas akademik Politeknik Negeri Kupang yang dilakukan melalui penyampaian surat kepada tiap unit dan jurusan di Politeknik Negeri Kupang ataupun melalui media sosial seperti WhatsApp. Adapun kelemahan dari penyampaian informasi melalui media surat (kertas) tidak dapat menjangkau seluruh civitas akademik PNK secara luas. Begitu juga dengan menggunakan media WhatsApp yang hanya menjangkau dosen yang tergabung dalam grup WhatsApp tersebut.

Saat ini di Politeknik Negeri Kupang sudah terdapat beberapa jurnal ilmiah yang diterbitkan secara berkala, yaitu jurnal Mitra, Saintec, Flash (Teknik Elektro), Juteks (Teknik Sipil), Jaka (Akuntansi), dan Bisman (Bisnis Manajemen). Dari hasil penelitian sebelumnya telah dilakukan penerapan jurnal elektronik (e-journal) untuk jurnal Flash dan Jaka menggunakan aplikasi e-journal berbasis open source yaitu Open Journal Systems (OJS). Berdasarkan rencana kerja dari Unit Penelitian dan Pengabdian Kepada Masyarakat Politeknik Negeri Kupang (UP2M PNK) yang berkoordinasi dengan pengelola jurnal bahwa akan diterapkan jurnal elektronik pada seluruh jurnal yang ada di lingkungan Politeknik Negeri Kupang (PNK).

Tujuan dari penelitian ini adalah mengembangkan sebuah website bagi UP2M PNK yang dapat membantu UP2M PNK dalam menyampaikan informasi terkait kegiatan penelitian dan pengabdian masyarakat di Politeknik Negeri Kupang, serta mengimplementasikan jurnal elektronik untuk seluruh jurnal yang ada di Politeknik Negeri Kupang menggunakan Open Journal Systems (OJS). Tahapan-tahapan dalam melakukan penelitian ini mengacu pada metode pengembangan web yang meliputi: (1) Analysis, (2) Design, (3) Generation, (4) Implementation.
\end{abstract}

Kata Kunci: Website, Jurnal Elektronik, e-Journal, OJS .

\section{PENDAHULUAN}

Salah satu tridarma perguruan tinggi adalah penelitian dan pengabdian kepada masyarakat. Saat ini, penelitian dan pengabdian kepada masyarakat yang dilakukan dalam lingkungan perguruan tinggi baik yang dilakukan oleh dosen maupun mahasiswa tidak hanya menjadi konsumsi internal perguruan tinggi, tetapi perlu 


\section{1 | Jurnal Ilmiah FLASH $\quad$ Volume 3 Nomor 2 Desember 2017}

untuk disebarluaskan kepada masyarakat luas melalui publikasi ilmiah. Publikasi ilmiah seorang dosen adalah hal yang terpenting dalam kinerja dosen selain mengajar, meneliti dan mengabdi. Publikasi ilmiah saat ini sedang mengalami perubahan besar, akibat terjadinya transisi dari format penerbitan cetak ke format elektronik. Publikasi ilmiah melalui jurnal elektronik memberikan kemudahan pengaksesan bagi siapapun, kapan saja dan dimana saja, lebih cepat dan efisien. Disamping itu, proses penerbitan lebih cepat, biaya penerbitan dan pengelolaan lebih murah, distribusi lebih cepat, dan jurnal lebih dikenal masyarakat. Jurnal elektronik juga dapat meningkatkan citra, reputasi, promosi, kredibilitas, dan penghargaan baik bagi institusi maupun penulis. Kelebihan jurnal elektronik dibanding dengan jurnal cetak antara lain: ditemukan cepat melalui search engine, mudah untuk dihubungkan (linking) dengan artikel lain, material pendukung dapat ditambahkan, dan pengguna artikel dapat dihitung dengan mudah (article impact). (Sumber: PDII LIPI).

Saat ini di lingkungan Politeknik Negeri Kupang sudah terdapat beberapa jurnal ilmiah yang diterbitkan secara berkala, yaitu jurnal Mitra, Saintec, Flash (Teknik Elektro), Juteks (Teknik Sipil), Jaka (Akuntansi), dan Bisman (Bisnis Manajemen), selanjutnya akan menyusul jurnal dari semua jurusan di Politeknik Negeri Kupang. Dari hasil penelitian sebelumnya telah dilakukan penerapan jurnal elektronik ( $e$ journal) untuk jurnal Flash dan Jaka menggunakan aplikasi e-journal berbasis open source yaitu Open Journal Systems (OJS). Berdasarkan rencana kerja dari Unit Penelitian dan Pengabdian Kepada Masyarakat Politeknik Negeri Kupang (UP2M PNK) yang berkoordinasi dengan pengelola jurnal bahwa akan diterapkan jurnal elektronik pada seluruh jurnal yang ada di lingkungan Politeknik Negeri Kupang (PNK).

Salah satu kegiatan UP2M PNK sebagai pengelola kegiatan penelitian dan pengabdian kepada masyarakat di Politeknik Negeri Kupang adalah menyampaikan informasi terkait pelaksanaan kegiatan penelitian dan pengabdian masyarakat kepada civitas akademik Politeknik Negeri Kupang yang dilakukan melalui penyampaian surat kepada tiap unit dan jurusan di Politeknik Negeri Kupang ataupun melalui media sosial seperti WhatsApp. Adapun kelemahan dari penyampaian informasi melalui media surat (kertas) tidak dapat menjangkau seluruh civitas akademik PNK secara luas. Begitu juga dengan menggunakan media WhatsApp yang hanya menjangkau dosen yang tergabung dalam grup WhatsApp tersebut.

Berdasarkan permasalahan tersebut di atas maka dipandang perlu untuk dilakukan pendekatan penyebaran informasi secara luas yaitu melalui media website yang dapat diakses kapan saja dan dari mana saja. Dengan adanya portal website UP2M PNK diharapkan semua informasi terkait pelaksanaan kegiatan penelitian dan pengabdian masyarakat di lingkungan Politeknik Negeri Kupang dapat disebarkan secara luas dan dapat diakses dengan mudah oleh tiap civitas akademik PNK. Begitu juga dengan jurnal elektronik sebagai media publikasi ilmiah dosen dan mahasiswa di Politeknik Negeri Kupang perlu untuk diintegrasikan pada portal website UP2M PNK.

\section{TINJAUAN PUSTAKA}

\subsection{Jurnal}

Jurnal menurut Kamus Besar Bahasa Indonesia (KBBI) adalah (buku) catatan harian; surat kabar harian; majalah yang khusus memuat artikel dalam satu bidang ilmu tertentu.

Definisi terbitan berkala ilmiah menurut Peraturan Menteri Pendidikan Nasional Republik Indonesia Nomor 22 Tahun 2011 adalah bentuk pemberitaan atau komunikasi yang memuat karya ilmiah dan diterbitkan secara terjadwal dalam bentuk tercetak dan/atau elektronik. Sedangkan tujuan dari terbitan berkala ilmiah adalah meregistrasi kegiatan kecendekiaan, menyertifikasi hasil kegiatan yang memenuhi persyaratan ilmiah, mendiseminiasikannya secara meluas kepada khalayak ramai, dan mengarsipkan semua 
Mauko' $^{1}$, Setiohardjo ${ }^{2}$, Noach $^{3}$, Pengembangan Website Unit Penelitian Dan Pengabdian Kepada Masyarakat Dan Penerapan Jurnal Elektronik Berbasis Open Source Di Politeknik Negeri Kupang

temuan hasil kegiatan kecendekiaan ilmuwan dan pandit yang dimuatnya.

E-journal (electronic journal, jurnal elektronik) adalah jurnal yang diterbitkan bukan dalam bentuk cetak namun dalam bentuk elektronik dan jurnal online. Pengelolaan jurnal secara online bukan diartikan jurnal sudah mempunyai site saja namun lebih dari itu, proses bisnis yang terjadi akan dilayani oleh sebuah aplikasi yang dapat diakses oleh semua stakeholder, mulai dari penerimaan naskah dari penulis, distribusi naskah, pemeriksaan naskah, penyuntingan naskah hingga penerbitan jurnal semua dapat dilakukan secara online serta semua aktor yang terlibat dalam terbitnya jurnal (penulis, editor, reviewer, dan sebagainya) akan menggunakan aplikasi ini secara online, tanpa harus saling bertemu secara langsung namun terhubung dalam satu aplikasi yang dapat diakses secara global.

\subsection{Open Journal Systems}

Open Journal Systems (OJS), yang dikembangkan oleh Public Knowledge Project (PKP), adalah sebuah software berbasis open source yang digunakan untuk publikasi jurnaljurnal penelitian suatu instansi, perguruan tinggi atau lainnya, atau dapat disebut juga sebagai software terpadu pengelolaan jurnal online. Dengan lisensi GNU General Public License, pihak ketiga diperbolehkan untuk mengubah OJS baik secara keseluruhan atau bagian tertentu sesuai dengan ketentuan dari lisensi ini. PKP juga menyambut baik penambahan patch untuk perbaikan bug pada perangkat lunak ini.

Saat ini OJS telah digunakan secara luas di Indonesia. Beberapa Perguruan Tinggi di Indonesia yang menggunakan OJS sebagai platform jurnal elektroniknya antara lain Universitas Gadjah Mada, Institut Teknologi Bandung, Universitas Negeri Semarang, Universitas Brawijaya dan masih banyak lagi perguruan tinggi negeri atau swasta yang menggunakan OJS.

Fitur dari OJS (Willinsky dkk, 2010) adalah sebagai berikut :

$>$ OJS diinstal dan dikontrol secara lokal.
a.Editor bisa mengatur kebutuhan, bagianbagian, proses review, dll.

b.Pendaftaran dan pengelolaan seluruh konten secara online.

c.Modul berlangganan dengan opsi untuk akses terbuka.

d.Pengindeksan konten secara luas.

e.Tersedia tools untuk membaca konten, berdasarkan pilihan judul dan penulis.

f.Pemberitahuan melalui email dan fitur komentar untuk pembaca.

g. Support bantuan online yang lengkap.

h.Modul pembayaran untuk biaya jurnal (artikel) yang diterima.

Kelebihan OJS (Surjono, 2009) antara lain adalah:

a.OJS beroperasi di multiple platform termasuk Windows

b.OJS bisa beroperasi dengan webserver Apache atau IIS

c.Proses instalasi mudah

d.Banyak tersedia dokumentasi

\subsection{Web}

Secara teknis, Web adalah sebuah sistem dengan informasi yang disajikan dalam bentuk teks, gambar, suara dan lain-lain yang tersimpan dalam sebuah server Web Internet yang disajikan dalam bentuk hiperteks. Informasi Web dalam bentuk teks umumnya ditulis dalam format HTML (Hypertext Markup Language). Informasi lainnya disajikan dalam bentuk grafis (dalam format GIF, JPG, PNG), suara (dalam format AU, WAV), dan objek multimedia lainnya (seperti MIDI, Shockwave, Quicktime Movie, 3D World) (Simarmata, 2010).

\section{METODE PENELITIAN}

Metode pengembangan web yang digunakan mengacu pada pendekatan yang dikemukakan oleh Howcroft dan Carrol (2000), dengan tahapan-tahapan sebagai berikut :

1)Tahap 1 - Analysis, tahap satu ini berkaitan dengan penetapan tujuan strategis pengembangan web dan analisis tentang bagaimana situs web dapat mencapai tujuan 


\section{Jurnal Ilmiah FLASH $\quad$ Volume 3 Nomor 2 Desember 2017}

strategis ini. Analisis ini dibagi menjadi 6 tugas, yaitu sebagai berikut:

a)Analisis Teknologi, identifikasi semua komponen teknologi dan peralatan yang dibutuhkan untuk membangun dan mendukung situs ini.

b)Analisis Informasi, identifikasi informasi yang dibutuhkan pengguna, baik statis (halaman web) atau dinamis (berdasarkan request ke server database).

c)Analisis keterampilan, identifikasi beragam keterampilan yang dibutuhkan untuk menyelesaikan proyek.

d)Analisis Pengguna, identifikasi semua pengguna situs yang dimaksud. Ini adalah proses yang jauh lebih kompleks daripada dengan pengembangan sistem informasi tradisional sebagai jangkauan pengguna, dan teknologi yang digunakan oleh pengguna, dapat sangat bervariasi.

e)Analisis Biaya, perkiraan biaya untuk pengembangan situs dihitung, atau perkiraan tentang apa yang dapat dicapai dengan anggaran yang telah ditentukan.

f) Analisis Risiko, analisis tentang risiko utama yang terkait dengan pengembangan situs ini.

2)Tahap 2 - Design, setelah tahap analisis selesai maka selanjutnya dilakukan perancangan sistem berdasarkan dokumen tujuan yang dihasilkan dari tahap pertama, diantaranya desain informasi yang menggambarkan struktur web, struktur data dan fungsi dari setiap fitur serta desain grafis yang meliputi tata letak, warna, gambar dan animasi. Pada tahap ini juga dilakukan pengujian terhadap desain untuk menemukan inkonsistensi atau kesalahan yang tidak sesuai dengan sasaran dan tujuan yang diuraikan pada tahap pertama serta untuk memastikan apakah sistem dapat menghasilkan informasi yang dibutuhkan oleh pengguna dengan benar.

3)Tahap 3 - Generation, tahapan ini mencakup pembangunan situs web berdasarkan dokumen desain. Semua sumber daya untuk pengembangan situs, seperti perangkat keras dan perangkat lunak akan dipilih selama langkah ini. Sejumlah aplikasi dan server yang berbeda mungkin perlu diintegrasikan, jadi spesifikasi teknis harus diperiksa untuk memastikan kompatibilitas. Langkah pengkodean melihat generasi semua perangkat lunak yang terhubung dengan situs dan pemasangannya ke server Web yang relevan. Ini mungkin hanya melibatkan posting situs ke server Web, tapi juga bisa melibatkan tugas yang lebih rumit, seperti koneksi database. Pengujian adalah salah satu bidang yang paling kompleks dan sulit dari proyek Web manapun. Ini bahkan lebih kompleks dari pada sistem informasi tradisional, karena aplikasi Web sering dikembangkan untuk sekelompok pengguna yang luas (sering tidak diketahui) di lingkungan teknologi yang berbeda. Situs Web harus diuji terhadap sebanyak mungkin lingkungan dan kombinasi teknologi ini agar memaksimalkan khalayak potensial.

4)Tahap 4 - Implementation, Fase Implementasi mungkin yang paling sederhana, namun bisa dibilang salah satu fase terpenting. Untuk memastikan pengunjung merasakan manfaat dari website maka kehadiran sebuah situs harus dirasakan dan isinya harus dianggap bernilai. Selama tahap ini, situs harus terdaftar di mesin pencari utama, bersama dengan metode promosi lainnya seperti memberi tahu newsgroup yang relevan, pencetakan alamat domain situs Web pada kop lembaga, kartu nama, dll. Pada tahap ini juga dilakukan maintenance atau perawatan sistem. Seiring pertumbuhan situs, biaya perawatan akan meningkat secara signifikan. Informasi yang disajikan di situs Web harus tepat waktu. Untuk alasan ini, penting agar situs dipantau secara teratur untuk memastikan bahwa informasi dan tautan, terutama tautan eksternal, harus up-to-date. Ada proses berkelanjutan untuk pengembang Web untuk mengadopsi teknologi baru yang tersedia. Ini dapat dinilai sehubungan dengan tujuan yang diuraikan dalam Tahap Satu, terutama tujuan yang tidak dapat dilaksanakan pada saat itu dan didokumentasikan dalam Daftar Keinginan. 
Pengulangan seluruh proses kemudian dapat dilakukan untuk menerapkan fitur baru dan menambah fungsionalitas situs Web. Tahap Empat menunjukkan bagaimana metodologi pengembangan situs Web harus bersifat iteratif dan digunakan secara nonlinear. Tinjauan Tujuan dapat dilakukan selama Tahap Tiga dan Daftar Keinginan yang diperiksa ulang. Ini berarti proses pembangunan akan kembali ke Tahap Satu.

\section{HASIL DAN PEMBAHASAN}

Berdasarkan tahapan-tahapan yang dilakukan sesuai dengan metode pengembangan web yang digunakan diperoleh hasil sebagai berikut:

1)Tahap 1, penetapan tujuan strategis pengembangan web yaitu tersedia sebuah media bagi UP2M PNK untuk menyampaikan informasi terkait kegiatan penelitian dan pengabdian masyarakat di PNK yang dapat diakses secara luas dengan mudah dari mana saja, serta tersedia sistem untuk melakukan pengelolaan jurnal secara elektronik yang dapat melayani setiap proses bisnis yang ada pada penerbitan sebuah jurnal yang dapat diakses oleh semua stakeholder, mulai dari penerimaan naskah dari penulis, distribusi naskah, pemeriksaan naskah, penyuntingan naskah hingga penerbitan jurnal semua dapat dilakukan secara online serta semua aktor yang terlibat dalam terbitnya jurnal (penulis, editor, reviewer, dan sebagainya) akan menggunakan sistem secara online, tanpa harus saling bertemu secara langsung namun terhubung dalam satu aplikasi yang dapat diakses secara global. Dari analisis yang dilakukan diperoleh hasil sebagai berikut:

a)Komponen teknologi yang dibutuhkan (kebutuhan minimum) adalah server database MySql 4.1 atau PostgreSq1 9.1.5, php 5.3.7 dan sistem operasi yang direkomendasikan berbasis Unix (seperti Linux, FreBSD, Solaris dll).

b)Identifikasi informasi yang dibutuhkan pengguna website dibagi menjadi pengelola
UP2M dapat memasukan informasi dan berita ke website UP2M kemudian pengunjung dapat melihat secara bebas informasi dan berita yang ada di website UP2M tanpa harus login terlebih dahulu.

c)Adapun keterampilan yang dibutuhkan untuk pengembangan sistem terdiri dari Sistem Analis yang bertugas mengerjakan tahap analisis dan desain, Programer yang bertugas mengerjakan pembuatan program (coding) berikut instalasi server web, serta Operator yang kemudian mengoperasikan sistem secara berkelanjutan.

d)Pengguna sistem dipisahkan menjadi pengguna jurnal elektronik dan pengguna website UP2M. Pengguna jurnal elektronik terdiri dari Penulis, Reviewer, Editor, dan Pengelola Jurnal, sedangkan pengguna website UP2M terdiri dari Operator, Admin dan pengunjung website. Pengguna dapat mengakses sistem menggunakan komputer yang memiliki jaringan internet termasuk didalamnya komputer mobile seperti notebook, netbook, ipad dan smartphone.

e)Dari ke-empat tahap dalam pengembangan web, biaya terbesar dibutuhkan pada tahap Generation atau pembuatan sistem, oleh karena itu dipilih sistem berbasis open source dan penerapan Content Management System (CMS) untuk meminimalisir biaya yang dibutuhkan untuk pembuatan sistem.

f) Risiko utama terkait dengan pengembangan sistem terletak pada kurangnya komitmen dari top management terkait pengembangan dan penerapan sistem secara berkelanjutan dalam hal ini adalah pengelola UP2M dan pengelola jurnal yang ada di PNK.

2)Tahap 2, pada tahap Desain dilakukan perancangan sistem yang meliputi pembuatan arsitektur sistem, peta situs dan Use Case Diagram.

a)Arsitektur Sistem, arsitektur sistem seperti ditunjukan pada Gambar 1 terdiri dari server web dan server e-journal. Sebagai konektifitas antar website UP2M dan ejournal, pada portal website UP2M disediakan hyperlink untuk menuju pada 


\section{| $105 \mid$ Jurnal Ilmiah FLASH Volume $3 \quad$ Nomor 2 Desember 2017}

portal jurnal elektronik Politeknik Negeri

Kupang.

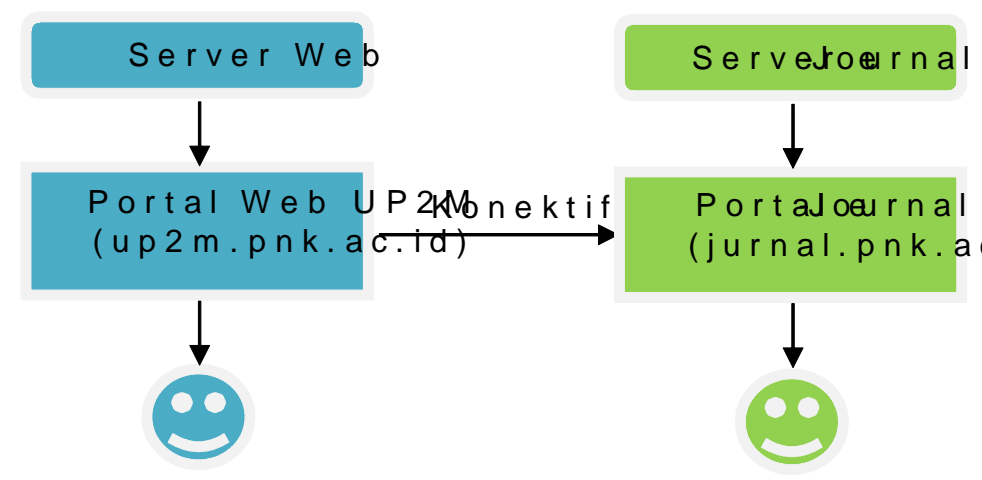

Gambar 1. Arsitektur Sistem

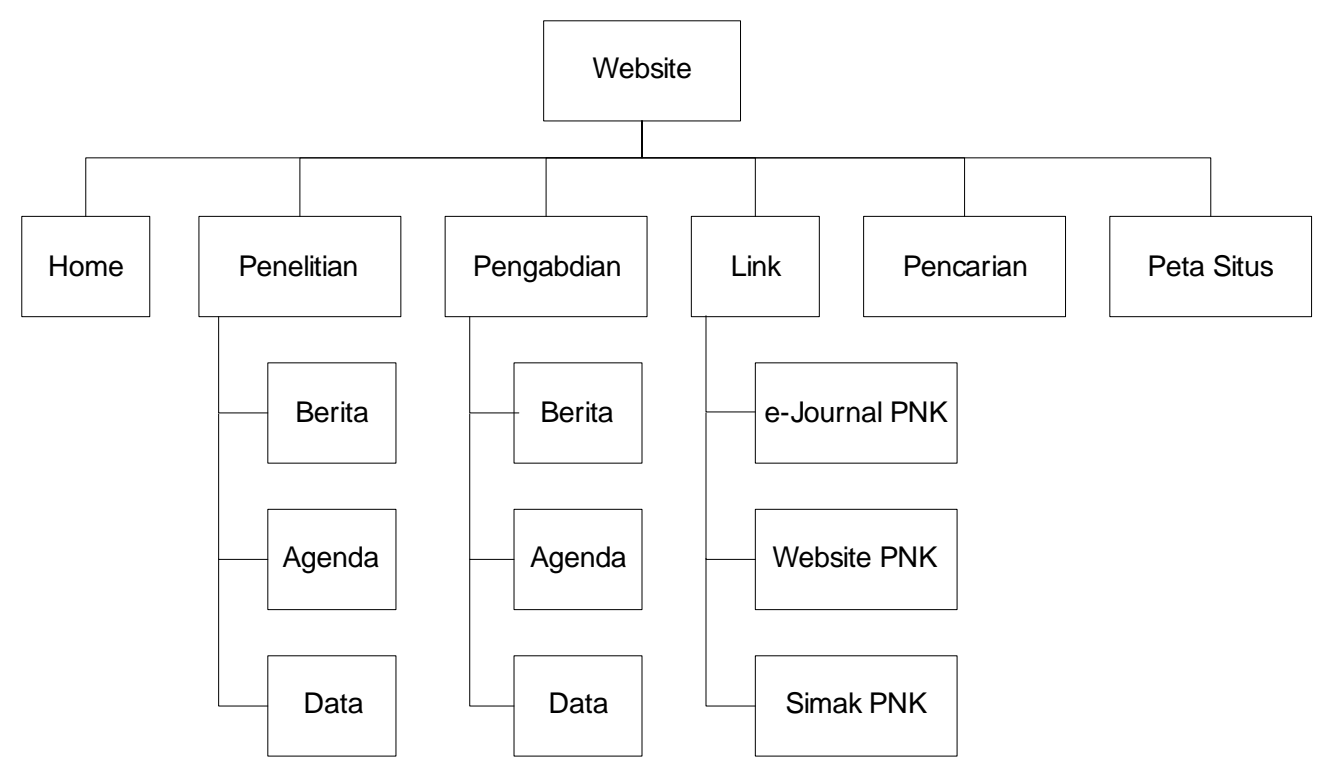

Gambar 2. Peta Situs

b)Peta Situs seperti yang ditunjukan pada Gambar 2 menunjukan bahwa pada website UP2M PNK terdapat menu utama yang terdiri dari Home, Penelitian, Pengabdian, Link, Pencarian dan Peta Situs. Pada menu Penelitian dan Pengabdian terdapat submenu Berita, Agenda dan Data.

c) Use Case Diagram seperti yang ditunjukan pada Gambar 3 menunjukan bahwa pada website UP2M PNK aktor dibagi menjadi tiga, yaitu pengunjung, operator dan admin. Operator diberikan akses untuk melihat berita, agenda dan data penelitian dan pengabdian. Operator mendapat hak untuk melakukan input data, berita dan agenda penelitian dan pengabdian, sedangkan admin ditambahkan hak untuk menghapus data dan melakukan validasi data. 


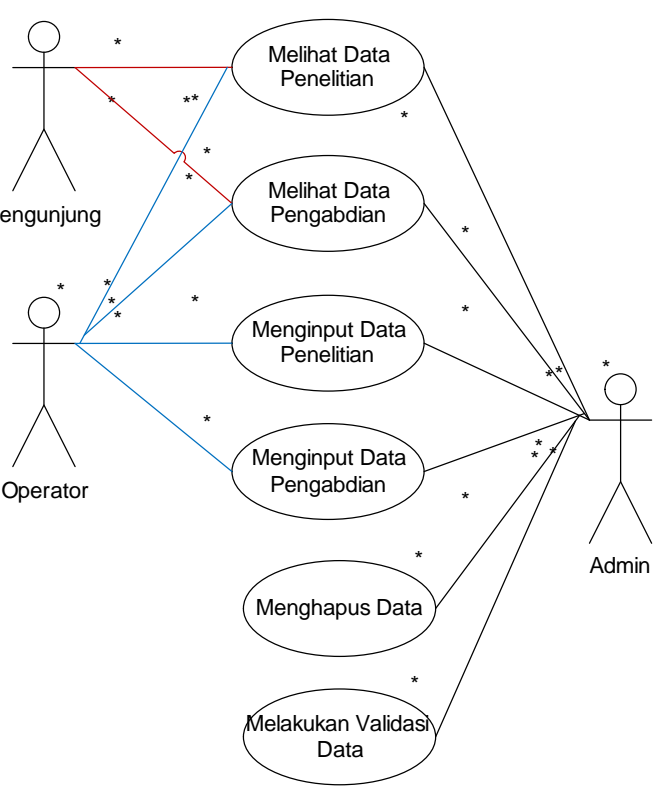

Gambar 3. Use Case Diagram

3)Tahap 3, tahapan ini mencakup pembangunan situs web berdasarkan hasil perancangan sistem yaitu dengan melakukan penulisan source code program untuk membangun sistem dengan menggunakan bahasa HTML dan CSS sebagai perancangan antarmuka dan PHP sebagai bahasa pemrograman yang membentuk logika dari pemrosesan sistem. Untuk sistem e-Journal dibuat dengan menggunakan software berbasis open source yaitu Open Journal Systems (OJS). Hasil dari penerapan OJS pada jurnal elektronik di PNK dapat dilihat pada Gambar 4.

Pada Tahap 3 ini juga dilakukan pengujian, baik pengujian pada sistem saat masih offline maupun yang sudah online. Dari pengujian yang dilakukan berdasarkan use case diagram didapatkan hasil bahwa tiap pengguna sistem dapat mengakses fitur-fitur sistem sesuai dengan batasan hak akses yang telah ditetapkan. Selanjutnya dilakukan pengujian performa sistem untuk menguji ketahanan sistem apabila diakses oleh banyak pengunjung secara bersamaan. Pengujian performa sistem dilakukan dengan menggunakan software Web Application Performance Testing (WAPT) versi 8.5 dengan skenario web akan diakses oleh 20 user dimana tiap 10 detik akan ada 10 user yang mengakses website dan durasi waktu pengujian dilakukan selama 10 menit. Berdasarkan hasil pengujian dapat dikatakan bahwa sistem memberikan waktu respon yang baik yaitu dibawah 1 detik hal ini ditunjukan oleh average response time yang diperoleh selama pengujian sebesar $95 \mathrm{~ms}$. Grafik hasil pengujian performa sistem dengan menggunakan WAPT dapat dilihat pada Gambar 5.

4)Tahap 4, dilakukan implementasi sistem sesuai dengan arsitektur sistem seperti pada Gambar 1. Karena keterbatasan hardware untuk komputer server maka penerapan server website UP2M PNK menggunakan server hosting yang disesuaikan dengan server hosting website PNK. Sedangkan server eJournal menggunakan dedicated server yang pengelolaannya dilakukan sendiri oleh UPT ICT PNK. Hal ini dilakukan atas pertimbangan bahwa server e-Journal memiliki laju pertumbuhan data yang lebih tinggi sehingga membutuhkan kapasitas penyimpanan yang lebih besar dibandingkan dengan server website UP2M PNK yang menggunakan server hosting dengan kapasitas penyimpanan yang lebih terbatas. Pada Tahap 4 ini juga dilakukan proses maintenance yang merupakan proses berkelanjutan untuk pengembangan web yang mengadopsi teknologi baru yang tersedia serta disesuaikan dengan adanya penambahan kebutuhan user terhadap fasilitas sistem. 
Gambar 4. Portal Jurnal Elektronik Politeknik Negeri Kupang

Gambar 5. Grafik Hasil Pengujian Performa Sistem Menggunakan WAPT

\section{KESIMPULAN}

a. Ada kesamaan antara metode pengembangan web yang digunakan dengan metode pengembangan sistem informasi tradisional yaitu terdapat tahap penetapan tujuan, pendefinisian kebutuhan, analisis, desain, pembuatan sistem (coding) dan implementasi. 
Mauko' $^{1}$, Setiohardjo ${ }^{2}$, Noach $^{3}$, Pengembangan Website Unit Penelitian Dan Pengabdian Kepada

Masyarakat Dan Penerapan Jurnal Elektronik Berbasis Open Source Di Politeknik Negeri Kupang

b.Dengan adanya website UP2M PNK dapat membantu UP2M PNK dalam menyampaikan informasi terkait kegiatan penelitian dan pengabdian masyarakat di Politeknik Negeri Kupang.

c.Pengelolaan jurnal elektronik dengan menggunakan Open Journal System dapat melayani setiap proses bisnis yang ada pada penerbitan sebuah jurnal mulai dari penerimaan naskah dari penulis, distribusi naskah, pemeriksaan naskah, penyuntingan naskah hingga penerbitan jurnal.

\section{DAFTAR PUSTAKA}

Howcroft, Debra. \& Carrol, John, 2000, A Proposed Methodology for Web Development, European Conference on Information Systems ECIS 2000 Proceedings 73.

Leaflet Pusat Dokumentasi dan Informasi Ilmiah LIPI, http://www.pdii.lipi.go.id/wp-content/ uploads/2014/02/Agenda-Pelatihan-PDIILIPI-2014.pdf.

Peraturan Menteri Pendidikan Nasional Republik Indonesia Nomor 17 Tahun 2010 tentang Pencegahan dan Penanggulangan Plagiat di Perguruan Tinggi: http:// unnes.ac.id/wp-content/uploads/PermenNomor-17-Thn-2010-tentang-pencegahandan-penanggulangan-plagiat.pdf.

manulangga, g., \& gultom, s. (2016). SISTEM

INFORMASI PENATALAYANAN

JEMAAT GEREJA HKBP KUPANG

BERBASIS WEB. Jurnal Ilmiah Flash, 2(2), 87-91. Retrieved from http:// jurnal.pnk.ac.id/index.php/flash/article/ view/29

Sudarmadji, P., \& Bani, A. (2017). PEMBUATAN APLIKASI PENDATAAN PADA SMA NEGERI 1 AMFOANG UTARA KABUPATEN KUPANG. Jurnal Ilmiah Flash, 3(1), 36-41. doi:10.5281/ zenodo. 1117133
Peraturan Menteri Pendidikan Nasional Republik Indonesia Nomor 22 Tahun 2011 tentang Terbitan Berkala Ilmiah: http:// www.dikti.go.id/files/atur/Permen222011Terbitan\%20BerkalaIlmiah.pdf.

Simarmata, Janner, 2010, Rekayasa Web, Penerbit Andi, Yogyakarta

Surat Edaran Dirjen Dikti No. 2050/E/T/2011 tentang Kebijakan Unggah Karya Ilmiah dan Jurnal tanggal 30 Desember 2011 http:/ /www.dikti.go.id/files/atur/SEDirjen2050E-T-2011UnggahKaryaIlmiah.pdf.

Surjono, Herman Dwi, 2009, Pengenalan dan Pengembangan E-Journal, http:// blog.uny.ac.id/hermansurjono/files/2009/ 09/Pengembangan-e-journal-herman-dsurjono-uny.pdf, diakses tanggal $14 \mathrm{Mei}$ 2014.

Willinsky, J., dkk, 2010, Open Journal Systems: A Complete Guide to Online Publishing, Simon Fraser University Library.

Zuchri, Lutfi, 2008, Open Journal Systems: Solusi Pengelolaan Jurnal Ilmiah, Ilmu Komputer.Com,http://ilmukomputer.org/ wp-content/uploads/2009/05/zuchri-ojssolusi-pengelolaan-jurnal-ilmiah.pdf, diakses tanggal 14 Mei 2014.

Dillak, R., \& toamnanu, n. (2017). SISTEM

INFORMASI PENELITIAN RUTIN

BERBASIS WEB DI UNIT PENELITIAN

DAN PENGABDIAN MASYARAKAT

RUTIN (UPPM) POLITEKNIK NEGERI

KUPANG. Jurnal Ilmiah Flash, 3(1), 17-27. doi:10.5281/zenodo.1117129 